\title{
Notes on occurrence of moths (Lepidoptera, Heterocera) in Ksany village in the commune of Opatowiec of the Świętokrzyskie Province
}

\author{
Klaudia Konop ${ }^{\mathrm{a}}$, Janusz Fyda ${ }^{\mathrm{a}, \mathrm{b}}$ * \\ ${ }^{a}$ University of Applied Sciences in Tarnow, ul. Mickiewicza 8, 33-100 Tarnów, Poland \\ ${ }^{b}$ Jagiellonian University in Kraków, Faculty of Biology, Institute of Environmental Sciences, ul. Gronostajowa 7 , \\ 30-387 Kraków, Poland
}

\section{Article history}

Received: 25 May 2020

Received in revised form:

22 June 2020

Accepted: 17 September 2020

Available: 29 September 2020

\begin{abstract}
On selected days from July to September 2017, the butterfly species with twilight and nocturnal activity in the village of Ksany in agriculturally and little anthropogenically transferred land were studied. Catching was done in the evening and night hours, using a method of the vividly attracting to the light. Flying moths were photographed on-site for later determination. A total of 13 catches were carried out with an average at intervals of 1-2 weeks. Over 60 moths species were determined, mostly belonging to the families Geometridae and Erebidae. When analyzing the results of catches, basic weather parameters such as temperature, air pressure and moon phase were taken into account.
\end{abstract}

Keywords: moths, nocturnal butterflies, Heterocera, Geometridae, Erebidae, rapid inventory

\section{Introduction}

The butterflies (lepidopterans and moths) are one of the best known among all groups of insects. Among more than 160 thousands species occurring worldwide, there are 3258 butterfly species described only in Poland and belonging to 69 families. Butterflies with the night activity called usually the moths belong to 164 families, while those with daily activity count only 6 families. However, despite this facts night butterflies are much less known than those which are active during the day [1]. The basis for the division of the whole group of butterflies into day and night species was the difference in the construction of the antennas. The diurnal species with the exception of the family Hedylidae, have thin antennae with a small balls or clubs at their end. In turn antennae of the moth are usually feathery with no ball on the end. Using this feature the group with "club-antennae" is called Rhopalocera and most of daily active butterflies were assigned to this group. To the Heterocera group belong nocturnal butterflies with a varied-antennae structure [2]. It is now widely known that this division, as well as the division into smaller (Microlepidoptera) and larger butterflies (Macrolepidoptera) does not correspond to modern views on phyogeny of butterflies, but it is often used for practical reasons [2].

* Corresponding author: janusz.fyda@uj.edu.pl
Some of the butterflies attributed to the Heterocera group lead a daily lifestyle, and the activity of certain species of day butterflies at dusk or at night is also observed. Morphological differences between individual families of butterflies are often visible at a glance. Those with nocturnal activity are characterized by thick body, covered with bristles, apparently larger scales on the wings, a variety of tentacles, for example pinnate or crested. They rest with wings folded roof or sideways, and their coloration is usually masking, although there are also some brightly colored species. In contrary, diurnal butterflies usually have a slender body, tentacles ending in a club form and colorful upper side of the wings. During rest they put their wings vertically above the body. Moths play important roles in many ecosystems as pollinators, herbivores, and prey for a wide range of species such as night birds and bats $[3,4]$. The distribution and ecology of moths are well known in comparison to many other invertebrates [5]. In recent decades, declines of moth populations have been observed in European countries. For instance in Great Britain the abundance of macro-moths decreased by $28 \%$ between 1968 and 2007 [5] and similar negative trends have been noticed in Sweden [6] and the Netherlands [7]. Such declines are expected to have cascading effects at both higher (bats, birds) and lower (plants) trophic levels as moths play the keystone role in many ecosystems $[4,8]$. 
There are many methods for observing and catching night butterflies, and one of the most well-known and commonly used is attracting them to the artificial light. For this purpose, a white screen and incandescent mercury bulbs (MIX), mercury vapor lamps (LRF), UV lamps or self-fishing lamps are usually used. Light traps can be designed in various ways and operated using different light sources; both of these modifications are known to affect trap performance $[9,10]$. Nowadays, also important modifications and improvements in traps were introduced as for example dedicated UV LED lamps with emitted electromagnetic spectrum wave length corresponding to the peak sensitivity in most Lepidoptera eye receptors for ultraviolet, blue and green [11]. Moreover the works of Infusino and collaborators [12] clearly shows the greater effectiveness of this light source in catching some moths genera in comparison to those caught by mercury vapour lamp traps. However, not only kind of light source but also weather factors, such as temperature and rainfall can influence catch size $[13,14]$. Because of many different factors which influenced trap efficiency the quantitative results are problematic and may restrict the value of monitoring data by complicating attempts to assess trends and compare results across studies and regions [15].
In this study we used light traps in an agricultural landscape of Ksany village which is a countryside in Świętokrzyskie province to make a catches of nocturnal butterflies. During the catching the basic weather parameters such as temperature, air pressure and moon phase were collected to assess their relationship with the activity and number of flying moths. Based on the outcome of these observations, we added some observations about moths occurrence and diversity of the studied station.

\section{Materials and methods}

In total, 13 catchings of moths were conducted on selected days from the 14 July to the 2 September 2017 and repeated for one month from the 12 May to 9 June 2018. The catching stand was located in the Koszycko-Opatowiec area of the protected landscape, directly near the ecological corridor running from the South to the North. The nearest East Mountains park is located about $11 \mathrm{~km}$ from the catchment site, and two Natura 2000 protected areas are only around $3.5 \mathrm{~km}$ away. These are the areas of Dolina Nidy (PLB 260001) and Ostoja Nidziańska (PLH 260003). The station of catches was in typically agricultural

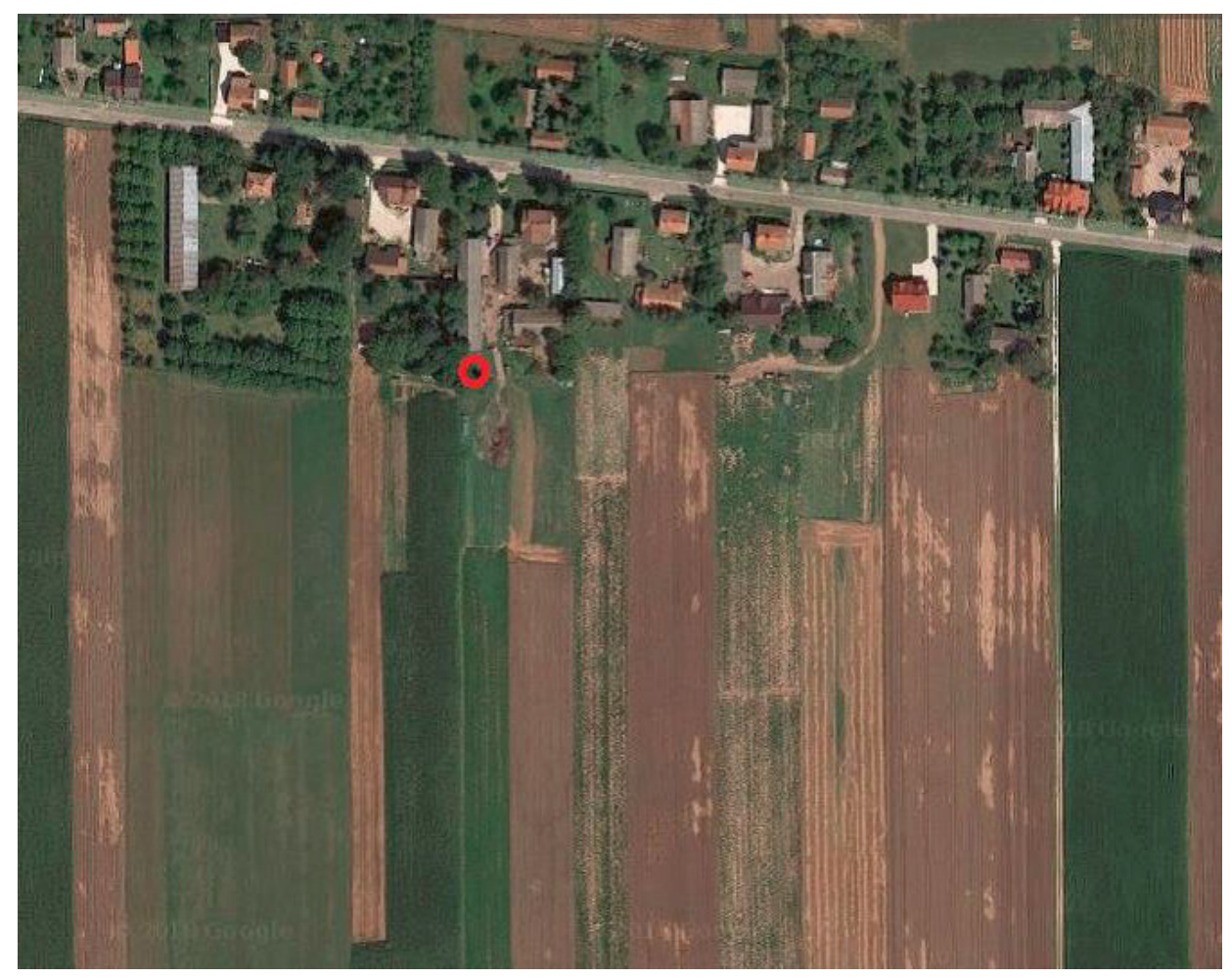

Figure 1. An aerial view of the area of the study with marked place of the screen location Source: geoserwis.gos.gov.pl. 
landscape, subjected by anthropopressure as the fields cultivation, houses and farm buildings (Fig. 1). The trap was on farm-

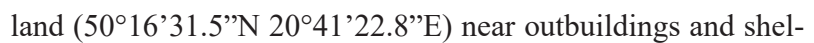
ters (Fig. 2) however, in surroundings there were also some orchards and a bit further meadows and forests.
The catching was done after sunset during evening and night usually between 9:00 p.m. and 1:00 a.m. For catching of the moths a live method was used, consisting in trap with white cotton screen $2 \mathrm{~m}$ high and 1,5 $\mathrm{m}$ width and attracting light. As a source of light the mercury LRF bulb of $125 \mathrm{~W}$ (POLAMP),

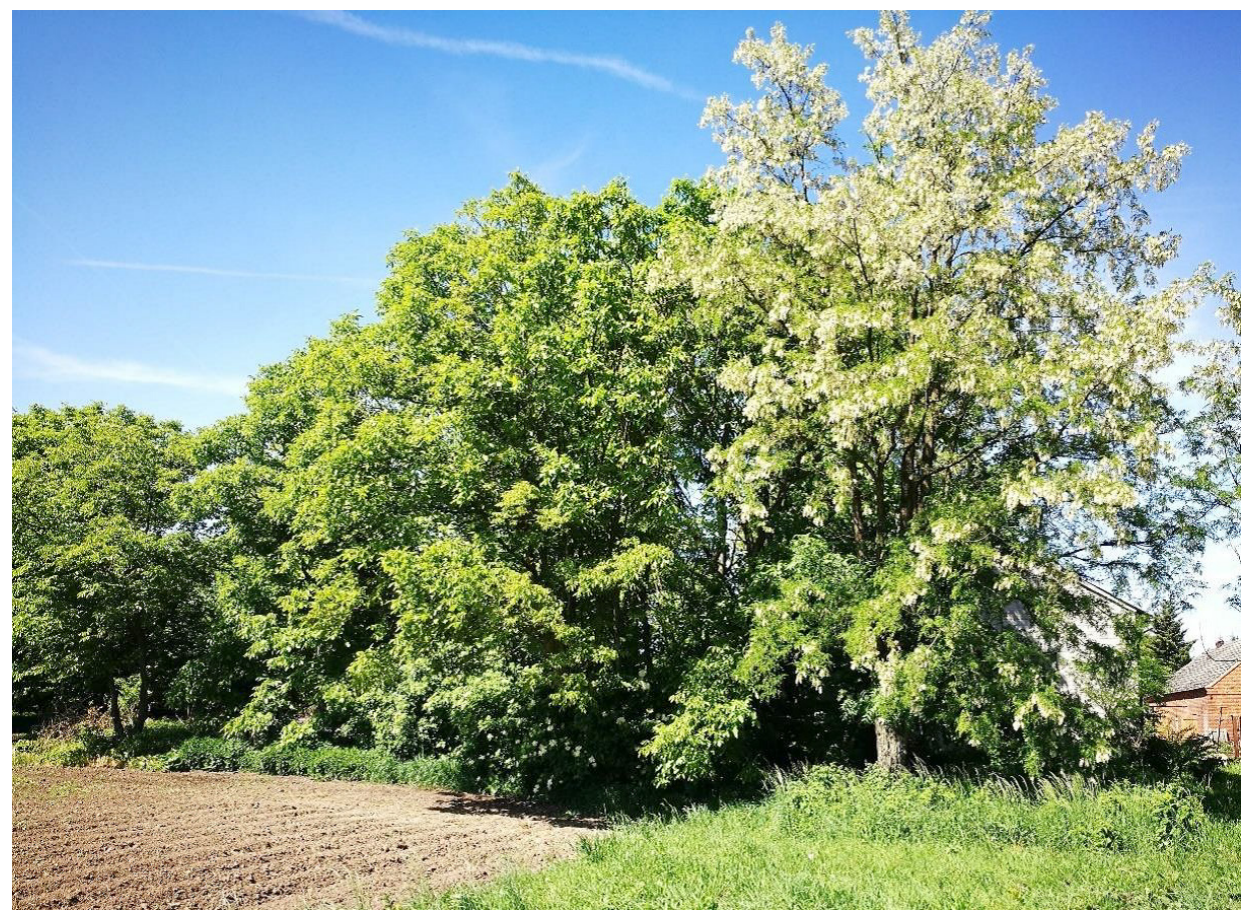

Figure 2. Station where the trap for catching moths was placed

neutral white light with a light color of $400 \mathrm{~K}$ and a luminous flux of $6700 \mathrm{~lm}$ were used. During the catching, the position of screen was sometimes changed, in order to find the most optimal arrangement. A screen was placed in two ways - on the ground, or hanging vertically as cylindrical tube with a light bulb in the middle. In both cases the light source was in distance of about $50 \mathrm{~cm}$ from the screen surface. Incoming and landing on the screen moths were photographed for documentation and later species determination which was done using the keys $[1,2,16,17,18]$ and web pages dedicated to butterflies e.g. [19]. The nocturnal activity of moth was estimated as general number of all specimens coming to the screen on a five-point scale where 1 (very low) means only single moths and 5 (very large) dozen of them in a unit of time. During the catching, values of mean air temperature, air pressure as well as wind direction and speed were collected from dedicated web page [20]. The phase of moon at night of sampling was noted according to the moon calendar on the website [21].

\section{Results and Discussion}

In this study catching and observation methodology was pro-ecological and consistent with the principles of nature protection. In total, during all of the catches almost 60 different forms of nocturnal butterflies were photographed and 46 of them were determined to the species level (Tab. 1). The caught individuals belonged to 12 families. Some of the representatives are shown on the figures 3,4 , and 5 . The most abundant was geometer moths belonging to the family Geometridae, from which 11 species were recognized. Next the most abundant in species family was Erebidae (10 species) followed by Noctuidae ( 8 species) and Sphingidae (5 species). The families Crambidae, Drepanidae, Notodontidae and Pterophoridae were represented by 2 species each while the families Lasiocampidae, Nolidae, Pyrialidae, and Cossidae were confirmed only with one representative respectively. The largest number of observed butterflies were the black arches [Lymantria (Lymantria) monacha (Linnaeus, 1758)] and white ermine [Spilosoma lubricipeda (Linnaeus, 1758)] from the Erebidae family (Tab. 1, Fig. 3). 
Table 1. List of nocturnal butterflies determined to the species level during catches with number of specimens observed and month of occurrence

\begin{tabular}{|c|c|c|c|c|}
\hline No. & Family & Species & $\begin{array}{l}\text { Number of } \\
\text { specimens }\end{array}$ & Month \\
\hline 1 & $\begin{array}{l}\text { Cossidae } \\
\text { Trociniarkowate }\end{array}$ & $\begin{array}{l}\text { Cossus cossus (Linnaeus, 1758) } \\
\text { Trociniarka czerwica }\end{array}$ & 2 & VIII \\
\hline 2 & $\begin{array}{l}\text { Crambidae } \\
\text { Wachlarzykowate }\end{array}$ & $\begin{array}{l}\text { Anania hortulata (Linnaeus, 1758), } \\
\text { Przezierka pokrzywianka }\end{array}$ & $>10$ & VI, VII, VIII \\
\hline 3 & $\begin{array}{l}\text { Crambidae } \\
\text { Wachlarzykowate }\end{array}$ & $\begin{array}{l}\text { Patania ruralis (Scopoli, 1763) } \\
\text { Boczanka brązowianka }\end{array}$ & $>5$ & VII, VIII \\
\hline 4 & $\begin{array}{l}\text { Drepanidae } \\
\text { Wycinkowate }\end{array}$ & $\begin{array}{l}\text { Habrosyne pyritoides (Hufnagel, 1766) } \\
\text { Pluszówka agatka }\end{array}$ & 1 & VI \\
\hline 5 & $\begin{array}{l}\text { Drepanidae } \\
\text { Wycinkowate }\end{array}$ & $\begin{array}{l}\text { Thyatira batis (Linnaeus, 1758) } \\
\text { Plamówka malinówka }\end{array}$ & 3 & VII \\
\hline 6 & $\begin{array}{l}\text { Erebidae } \\
\text { Mrocznicowate }\end{array}$ & $\begin{array}{l}\text { Arctia caja (Linnaeus, 1758) } \\
\text { Niedźwiedziówka kaja }\end{array}$ & 1 & VIII \\
\hline 7 & $\begin{array}{l}\text { Erebidae } \\
\text { Mrocznicowate }\end{array}$ & $\begin{array}{l}\text { Catocala fulminea (Scopoli, 1763) } \\
\text { Wstęgówka śliwica }\end{array}$ & 1 & VII \\
\hline 8 & $\begin{array}{l}\text { Erebidae } \\
\text { Mrocznicowate }\end{array}$ & $\begin{array}{l}\text { Laspeyria flexula } \\
\text { (Denis \& Schiffermüller, 1775) }\end{array}$ & 3 & VI, VII \\
\hline 9 & $\begin{array}{l}\text { Erebidae } \\
\text { Mrocznicowate }\end{array}$ & $\begin{array}{l}\text { Lymantria (Porthetria) dispar } \\
\text { (Linnaeus, 1758) Brudnica nieparka }\end{array}$ & $>10$ & VII, VIII \\
\hline 10 & $\begin{array}{l}\text { Erebidae } \\
\text { Mrocznicowate }\end{array}$ & $\begin{array}{l}\text { Lymantria (Lymantria) monacha } \\
\text { (Linnaeus, 1758) Brudnica mniszka }\end{array}$ & $>20$ & VII, VIII, IX \\
\hline 11 & $\begin{array}{l}\text { Erebidae } \\
\text { Mrocznicowate }\end{array}$ & Paracolax tristalis (Fabricius, 1794) & 4 & VI, VII \\
\hline 12 & $\begin{array}{l}\text { Erebidae } \\
\text { Mrocznicowate }\end{array}$ & $\begin{array}{l}\text { Phragmatobia fuliginosa (Linnaeus, 1758) } \\
\text { Sadzanka rumienica }\end{array}$ & $>10$ & V, VII, VIII \\
\hline 13 & $\begin{array}{l}\text { Erebidae } \\
\text { Mrocznicowate }\end{array}$ & $\begin{array}{l}\text { Spilosoma lubricipeda (Linnaeus, 1758) } \\
\text { Szewnica miętówka }\end{array}$ & $>5$ & VII, VIII \\
\hline 14 & $\begin{array}{l}\text { Erebidae } \\
\text { Mrocznicowate }\end{array}$ & $\begin{array}{l}\text { Spilosoma urticae (Esper, 1789) } \\
\text { Szewnica pokrzywówka }\end{array}$ & $>20$ & V, VI,VII, VIII \\
\hline 15 & $\begin{array}{l}\text { Erebidae } \\
\text { Mrocznicowate }\end{array}$ & $\begin{array}{l}\text { Hypena proboscidalis (Linnaeus, 1758) } \\
\text { Rozszczepka śnicianka }\end{array}$ & $>5$ & VII, VIII \\
\hline 16 & $\begin{array}{l}\text { Geometridae } \\
\text { Miernikowcowate }\end{array}$ & $\begin{array}{l}\text { Biston betularia (Linnaeus, 1758) } \\
\text { Krępak nabrzozak }\end{array}$ & $>5$ & VII \\
\hline 17 & $\begin{array}{l}\text { Geometridae } \\
\text { Miernikowcowate }\end{array}$ & $\begin{array}{l}\text { Camptogramma bilineata (Linnaeus, 1758) } \\
\text { Paśnik goździeniak }\end{array}$ & 2 & VII \\
\hline 18 & $\begin{array}{l}\text { Geometridae } \\
\text { Miernikowcowate }\end{array}$ & $\begin{array}{l}\text { Campaea honoraria } \\
\text { (Denis \& Schiffermüller, 1775) } \\
\text { Ostrolot dębowiak }\end{array}$ & 1 & VIII \\
\hline 19 & $\begin{array}{l}\text { Geometridae } \\
\text { Miernikowcowate }\end{array}$ & $\begin{array}{l}\text { Comibaena bajularia } \\
\text { (Denis \& Schiffermüller, 1775) } \\
\text { Miernik plamiak }\end{array}$ & 1 & VI \\
\hline 20 & $\begin{array}{l}\text { Geometridae } \\
\text { Miernikowcowate }\end{array}$ & $\begin{array}{l}\text { Ennomos erosaria } \\
\text { (Denis \& Schiffermüller, 1775) } \\
\text { Latalec gruszak }\end{array}$ & 2 & VI, VIII \\
\hline 21 & $\begin{array}{l}\text { Geometridae } \\
\text { Miernikowcowate }\end{array}$ & $\begin{array}{l}\text { Ennomos fuscantaria (Haworth, 1809) } \\
\text { Latalec najesioniak }\end{array}$ & 1 & VII \\
\hline 22 & $\begin{array}{l}\text { Geometridae } \\
\text { Miernikowcowate }\end{array}$ & $\begin{array}{l}\text { Epirrhoe alternata (Müller, 1764) } \\
\text { Paśnik zmiennik }\end{array}$ & $>5$ & VI, VII, VIII \\
\hline 23 & $\begin{array}{l}\text { Geometridae } \\
\text { Miernikowcowate }\end{array}$ & $\begin{array}{l}\text { Eupithecia centaureata } \\
\text { (Denis \& Schiffermüller, 1775) } \\
\text { Grotnik chabrowiak }\end{array}$ & 1 & VI \\
\hline 24 & $\begin{array}{l}\text { Geometridaee } \\
\text { Miernikowcowate }\end{array}$ & $\begin{array}{l}\text { Hemithea aestivaria (Hübner, 1789) } \\
\text { Miernik kreskowiak }\end{array}$ & 1 & VIII \\
\hline
\end{tabular}




\begin{tabular}{|c|c|c|c|c|}
\hline No. & Family & Species & $\begin{array}{l}\text { Number of } \\
\text { specimens }\end{array}$ & Month \\
\hline 25 & $\begin{array}{l}\text { Geometridae } \\
\text { Miernikowcowate }\end{array}$ & $\begin{array}{l}\text { Hypomecis roboraria } \\
\text { (Denis \& Schiffermüller, 1775) } \\
\text { Przylepek nadębek }\end{array}$ & $>5$ & V, VI, VII \\
\hline 26 & $\begin{array}{l}\text { Geometridae } \\
\text { Miernikowcowate }\end{array}$ & $\begin{array}{l}\text { Lomaspilis marginata (Linnaeus, 1758) } \\
\text { Plamiec nabuczak }\end{array}$ & $>5$ & VI, VIII \\
\hline 27 & $\begin{array}{l}\text { Lasiocampidae } \\
\text { Barczatkowate }\end{array}$ & $\begin{array}{l}\text { Odonestis pruni (Linnaeus, 1758) } \\
\text { Barczatka śliwienica }\end{array}$ & $>10$ & VI, VII \\
\hline 28 & $\begin{array}{l}\text { Noctuidae } \\
\text { Sówkowate }\end{array}$ & $\begin{array}{l}\text { Acronicta (Viminia) rumicis } \\
\text { (Linnaeus, 1758) } \\
\text { Wieczernica szczawiówka }\end{array}$ & $>10$ & V, VII, VIII, IX \\
\hline 29 & $\begin{array}{l}\text { Noctuidae } \\
\text { Sówkowate }\end{array}$ & $\begin{array}{l}\text { Acontia (Emmelia) trabealis } \\
\text { (Scopoli, 1763) } \\
\text { Polnica szachowniczka }\end{array}$ & 3 & VI, VIII \\
\hline 30 & $\begin{array}{l}\text { Noctuidae } \\
\text { Sówkowate }\end{array}$ & $\begin{array}{l}\text { Diachrysia chrysitis (Linnaeus, 1758) } \\
\text { Błyszczka spiżówka }\end{array}$ & $>10$ & $\begin{array}{l}\text { V, VI, VII, VIII, } \\
\text { IX }\end{array}$ \\
\hline 31 & $\begin{array}{l}\text { Noctuidae } \\
\text { Sówkowate }\end{array}$ & Diachrysia stenochrysis (Warren, 1913) & $>5$ & V, VIII, IX \\
\hline 32 & $\begin{array}{l}\text { Noctuidae } \\
\text { Sówkowate }\end{array}$ & $\begin{array}{l}\text { Mythimna (Mythimna) pallens } \\
\text { (Linnaeus, 1758) } \\
\text { Mokradlica }\end{array}$ & $>5$ & VII, VIII, IX \\
\hline 33 & $\begin{array}{l}\text { Noctuidae } \\
\text { Sówkowate }\end{array}$ & $\begin{array}{l}\text { Noctua fimbriata (Schreber, 1759) } \\
\text { Rolnica aksamitka }\end{array}$ & 1 & VI \\
\hline 34 & $\begin{array}{l}\text { Noctuidae } \\
\text { Sówkowate }\end{array}$ & $\begin{array}{l}\text { Plusia festucae (Linnaeus, 1758) } \\
\text { Złocica kostrzewica }\end{array}$ & 1 & VII \\
\hline 35 & $\begin{array}{l}\text { Noctuidae } \\
\text { Sówkowate }\end{array}$ & $\begin{array}{l}\text { Trachea atriplicis (Linnaeus, 1758) } \\
\text { Agatówka łobodnica }\end{array}$ & 3 & VIII, IX \\
\hline 36 & $\begin{array}{l}\text { Nolidae } \\
\text { Rozeliowate }\end{array}$ & $\begin{array}{l}\text { Pseudoips prasinana (Linnaeus, 1758) } \\
\text { Zielonka ukośnica }\end{array}$ & 1 & VIII \\
\hline 37 & $\begin{array}{l}\text { Notodontidae } \\
\text { Garbatkowate }\end{array}$ & $\begin{array}{l}\text { Cerura (Apocerura) erminea (Esper, 1783) } \\
\text { Widłogonka gronostajka }\end{array}$ & 1 & V \\
\hline 38 & $\begin{array}{l}\text { Notodontidae } \\
\text { Garbatkowate }\end{array}$ & $\begin{array}{l}\text { Notodonta tritophus } \\
\text { (Denis \& Schiffermüller, 1775) }\end{array}$ & 1 & VI \\
\hline 39 & $\begin{array}{l}\text { Pterophoridae } \\
\text { Piórolotkowate }\end{array}$ & Oxyptilus pilosellae (Zeller, 1841) & 1 & VIII \\
\hline 40 & $\begin{array}{l}\text { Pterophoridae } \\
\text { Piórolotkowate }\end{array}$ & $\begin{array}{l}\text { Emmelina monodactyla (Linnaeus, 1758) } \\
\text { Piórolotek zwyczajny }\end{array}$ & $>10$ & VI, VII, VIII, IX \\
\hline 41 & $\begin{array}{l}\text { Pyralidae } \\
\text { Omacnicowate }\end{array}$ & Hypsopygia costalis (Fabricius, 1775) & 1 & VIII \\
\hline 42 & $\begin{array}{l}\text { Sphingidae } \\
\text { Zawisakowate }\end{array}$ & $\begin{array}{l}\text { Deilephila elpenor (Linnaeus, 1758) } \\
\text { Zmrocznik gładysz }\end{array}$ & $>10$ & V, VI, VII \\
\hline 43 & $\begin{array}{l}\text { Sphingidae } \\
\text { Zawisakowate }\end{array}$ & $\begin{array}{l}\text { Deilephila porcellus (Linnaeus, 1758) } \\
\text { Zmrocznik pazik }\end{array}$ & $>15$ & V, VI, VII \\
\hline 44 & $\begin{array}{l}\text { Sphingidae } \\
\text { Zawisakowate }\end{array}$ & $\begin{array}{l}\text { Laothoe populi (Linnaeus, 1758) } \\
\text { Nastrosz topolowiec }\end{array}$ & 2 & VIII \\
\hline 45 & $\begin{array}{l}\text { Sphingidae } \\
\text { Zawisakowate }\end{array}$ & $\begin{array}{l}\text { Sphinx ligustri (Linnaeus, 1758) } \\
\text { Zawisak tawulec }\end{array}$ & 2 & VI \\
\hline 46 & $\begin{array}{l}\text { Sphingidae } \\
\text { Zawisakowate }\end{array}$ & $\begin{array}{l}\text { Sphinx pinastri (Linnaeus, 1758) } \\
\text { Zawisak borowiec }\end{array}$ & 1 & VII \\
\hline
\end{tabular}

When compared with other studies, the number of noticed moths species was moderate. For example Nowacki and Pałka [22] in the ecosystems of the Nowa Dęba Training Area in the years 1999-2013 found 273 species of noctuid moths from the families Nolidae, Erebidae and Noctuoidae which constituted about $55 \%$ of the Polish Noctuoidae. However, smaller number of species in our study can be a result of the used method, shorter time of trapping and other different reasons as for example different landscape which was certainly more influenced by anthropomorphic changes and light pollution.

The most interesting butterflies that have been observed were the goat moth [Cossus cossus, (Linnaeus, 1758)], which is one of the largest indigenous which adults reach the size $59-96 \mathrm{~mm}$ (Fig. 5.5), the lesser puss moth [Cerura (Apocerura) erminea 
(Esper, 1783)] (Fig. 5.7), which is quite rare and noted only on several sites in Poland. This observation leads us to the conclusion that the study area which is in ecological corridor between different ecosystems of South Poland plays an important role for the moth biodiversity which was noticed in the early $20^{\text {th }}$ century in the Sandomierz Basin by Karpowicz [23] and Kulesza [24] who gave a list of 302 species which were mostly confirmed by Bielewicz [25, 26] and Nowacki and Pałka in 2015 [22].

The largest number of moths lured to the light during single catching was observed at night 9/10 June 2018 (Tab. 2). That night was reported with high air temperature reaching $21^{\circ} \mathrm{C}$ and low wind speed reached mean $6 \mathrm{~km} / \mathrm{h}$. At that night the $\mid$ moon was in the last quarter of lunar period (Tab. 2). The weather conditions were very similar to those at night from 4 to 5 July 2017, where also the high density and big activity of the night butterflies was observed. In contrary the smallest numbers of moths arriving to the light trap were recorded at nights on 14/15 and 25/26 August 2017, as well as on 2/3 September 2017 (Tab. 2). At that time of catching, the air temperature was quite low and reached on average $14^{\circ} \mathrm{C}, 16^{\circ} \mathrm{C}$ and $12^{\circ} \mathrm{C}$ respectively. The atmospheric pressure was between 1018 and $1025 \mathrm{hPa}$, and the average wind speed was $10 \mathrm{~km} / \mathrm{h}$. It is well known that the diversity of species noticed in station during field studies is strongly related to the number of samples taken and the sampling effort [27]. Explicit calculation of the rarefaction diversity measurement and the determination of sufficient sample size is necessary [28]. We are aware of the limitations of our study and because of this our results can only be treated as faunistic notes. Similarly quantitative data can be only assumed because of used pro-ecological method of catching which gave no possibility to count reliably abundance data. This could be solved in future studies by using other trap method or by involving several team members to count and observe trap screen simultaneously at the same time.

Table 2. Comparison of moth nocturnal activity, moon phases and weather conditions during all catches

\begin{tabular}{|c|c|c|c|c|c|c|}
\hline \multirow{2}{*}{ No. } & \multirow{2}{*}{ Night } & \multirow{2}{*}{$\begin{array}{l}\text { Density and } \\
\text { activity }^{1}\end{array}$} & \multirow{2}{*}{ Moon phase } & \multicolumn{3}{|c|}{ Weather parameters } \\
\hline & & & & $\begin{array}{c}\text { Mean temperature } \\
\left({ }^{\circ} \mathrm{C}\right)\end{array}$ & Air pressure $(\mathrm{hPa})$ & $\begin{array}{l}\text { Mean wind speed } \\
(\mathrm{km} / \mathrm{h})\end{array}$ \\
\hline 1 & $14 / 15.07 .2017$ & 2 & & 15 & 1015 & 7 \\
\hline 2 & 29/30.07.2017 & 2 & & 16 & 1018 & 10 \\
\hline 3 & $4 / 5.08 .2017$ & 4 & & 21 & 1012 & 5 \\
\hline 4 & $5 / 6.08 .2017$ & 3 & & 18 & 1015 & 7 \\
\hline 5 & $14 / 15.08 .2017$ & 1 & & 14 & 1025 & 10 \\
\hline 6 & 18/19.08.2017 & 3 & & 20 & 1015 & 11 \\
\hline 7 & $19 / 20.08 .2017$ & 2 & & 18 & 1020 & 4 \\
\hline 8 & $25 / 26.08 .2017$ & 1 & & 16 & 1018 & 8 \\
\hline 9 & $1 / 2.09 .2017$ & 2 & & 17 & 1012 & 7 \\
\hline 10 & 2/3.09.2017 & 1 & & 12 & 1018 & 9 \\
\hline 11 & $12 / 13.05 .2018$ & 3 & & 16 & 1022 & 5 \\
\hline 12 & 25/26.05 2018 & 3 & & 16 & 1010 & 4 \\
\hline 13 & $9 / 10.06 .2018$ & 5 & & 21 & 1012 & 6 \\
\hline
\end{tabular}

${ }^{1}$ Moth density: 1 - very low; 2-low; 3-medium; 4-large; 5-very large. 
Not only kind of trap but also weather conditions such as temperature and rain can influence catch size $[13,14]$. The warmer the night was the higher number of moths was caught [14] while the high humidity negatively affected moth abundance [29]. Our light trapping sessions were conducted in rather good weather conditions, however results of catches can be influenced by the moths susceptibility to the light, light range of the bulb which could be lower because of light pollution in village as well as a moon phase which during catching was mostly waxing or waning moon quarter but not new or full moon.

\section{Conclusions}

Moths are the richest in species group of Lepidoptera, however the diurnal butterflies are the most known. During catches in Ksany village 60 different morphotypes of moths were found from which 44 were identified to the species level. The moths activity depends on many factors among which weather conditions especially temperature played an important role. More detailed studies are needed in order to gather more precise information about diversity and abundance of nocturnal butterflies.

\section{Acknowledgments}

We would like to thank the anonymous reviewer for valuable comments on earlier version of the manuscript and Ms Agata Fyda for help with editing of the text. This research was funded by own founds of Department of Environmental Protection of the University of Applied Sciences in Tarnow.

\section{Author Contributions}

Conceptualization, Janusz Fyda and Klaudia Konop; methodology, Janusz Fyda and Klaudia Konop; software, Klaudia Konop; validation, Klaudia Konop and Janusz Fyda; formal analysis, Klaudia Konop and Janusz Fyda; investigation, Klaudia Konop; resources, Klaudia Konop; data curation, Klaudia Konop; writing — original draft preparation, Klaudia Konop; writing - review and editing, Janusz Fyda; visualization, Klaudia Konop and Janusz Fyda; supervision, Klaudia Konop; project administration, Klaudia Konop and Janusz Fyda; funding acquisition, Klaudia Konop and Janusz Fyda.

\section{References}

1. Buszko J, Masłowski J. Motyle dzienne Polski. Nowy Sącz: Koliber; 2015.
2. Buszko J, Masłowski J. Motyle nocne Polski Macrolepidoptera. Vol. 1. Nowy Sącz: Koliber; 2012

3. Vaughan N. The diets of British bats (Chiroptera). Mammal Review. 1997;27:77-94. https://doi.org/10.1111/j.1365-2907. 1997.tb00373.x.

4. Wickramasinghe LP, Harris S, Jones G, Vaughan Jennings N. Abundance and species richness of nocturnal insects on organic and conventional farms: effects of agricultural intensification on bat foraging. Conservation Biology. 2004;18(5):1283-1292. https://doi.org/10.1111/ wj.1523-1739.2004.00152.x.

5. Fox R, Parsons MS, Chapman JW, Woiwod IP, Warren MS, Brooks DR. (2013) The state of Britain's larger moths 2013. Wareham, Dorset: Butterfly Conservation and Rothamsted Research; 2013.

6. Franzén M, Johannesson M. Predicting extinction risk of butterflies and moths (Macrolepidoptera) from distribution patterns and species characteristics. Journal of Insect Conservation. 2007;11:367-390. https://doi.org/10.1007/ s10841-006-9053-6.

7. Groenendijk D, Ellis WN. The state of the Dutch larger moth fauna. Journal of Insect Conservation. 2011;15:95101. https://doi.org/10.1007/s10841-010-9326-y.

8. Jonason D, Franzén M, Pettersson LB. Transient peak in moth diversity as a response to organic farming. Basic and Applied Ecology. 2013;14(6):515-522. https://doi. org/10.1016/ j.baae.2013.07.003.

9. Fayle TM, Sharp RE, Majerus MEN. The effect of moth trap type on catch size and composition in British Lepidoptera. British Journal of Entomology and Natural History. 2007;20(4):221-232.

10. Intachat J, Woiwod IP. Trap design for monitoring moth biodiversity in tropical rainforests. Bulletin of Entomological Research. 1999;89:153-163.

11. Brehm G. A new LED lamp for the collection of nocturnal Lepidoptera and a spectral comparison of light-trapping lamps. Nota Lepidopterologica 2017;40(1):87-108. https:// doi.org/10.3897/nl.40.11887.

12. Infusino M, Brehm G, Di Marco C, Scalercio S. Assessing the efficiency of UV LEDs as light sources for sampling the diversity of macro-moths (Lepidoptera). European Journal of Entomology. 2017;114:25-33. https://doi.org/10.14411/ eje.2017.004.

13. Butler L, Kondo V, Barrows E, M., Townsend EC. Effects of weather conditions and trap types on sampling for richness and abundance of forest macrolepidoptera. Environmental Entomology. 1999;28(5):795-811. https://doi.org/10.1093/ ee/28.5.795. 
14. Yela JL, Holyoak M. Effects of moonlight and meteorological factors on light and bait trap catches of noctuid moths (Lepidoptera: Noctuidae). Environmental Entomology. 1997;26(6):1283-1290. https://doi.org/10.1093/ ee/26.6.1283.

15. EASAC. A user's guide to biodiversity indicators. London: European Academy of Science Advisory Council; 2004.

16. Amann G. (2009). Owady: kieszonkowy atlas najważniejszych chrząszczy, motyli i innych owadów lasów Europy Środkowej oraz ich stadiów rozwojowych i żerowisk, zawierający opisy poszczególnych gatunków. Warszawa: Multico Oficyna Wydawnicza; 2009.

17. Twardowski J, Twardowska K. Atlas motyli: 250 gatunków motyli. Warszawa: Wydawnictwo SBM; 2014.

18. Bellmann H. Atlas motyli: poradnik obserwatora. 2nd ed. Warszawa: Wydawnictwo RM; 2015.

19. Jonko Ch. Lepidoptera Mundi. 2020. Available at: https://lepidoptera.eu.

20. InfoMeteo.pl. Pogoda w Kazimierzy Wielkiej [weather forecast website]. Available at: http://kazimierza-wielka. infometeo.pl.

21. Timeanddate.com. Moon Phases 2020 - Lunar Calendar. Available at: https://www.timeanddate.com/moon/phases/.

22. Nowacki J, Pałka K. Noctuid moths (Lepidoptera: Noctuoidea: Nolidae, Erebidae, Noctuidae) of the Nowa Dęba Military Training Area in the Sandomierz primeval forest (south-eastern Poland). Fragmenta Faunistica. 2015;8(1):21-36.

23. Karpowicz S. Spis łuskoskrzydłych Ziemi Sandomierskiej II. Polskie Pismo Entomologiczne. 1928;7:93-122.

24. Kulesza W. Przyczynek do znajomości fauny motyli niektórych okolic Polski. Sprawozdania Komisji Fizjograficznej PAU. 1936;70:139-148.

25. Bielewicz M. (1973). Motyle Bieszczadów Zachodnich i Pogórza Przemyskiego. Cz. 1 tzw. Macrolepidoptera. Roczniki Muzeum Górnośląskiego w Bytomiu: Przyroda. 1973;7:1-170.

26. Bielewicz M. Nowe gatunki motyli większych (Macrolepidoptera) dla fauny Bieszczadów zachodnich i Pogórza Przemyskiego. Polskie Pismo Entomologiczne. 1984;54:407-409.

27. Heck KL, Van Belle G Jr, Simberloff D. Explicit calculation of the rarefaction diversity measurement and the determination of sufficient sample size. Ecology. 1975;6:1459-1461. https://doi.org/10.2307/1934716.

28. Raup DM. Taxonomic diversity estimation using rarefaction. Paleobiology. 1975;1(4):333-342. https://doi. org/10.1017/S0094837300002633.

29. Van Langevelde F, Ettema JA, Donners M, Wallis De Vries MF, Groenendijk D. Effect of spectral composition of artificial light on the attraction of moths. Biological Conservation. 2011;144(9):2274-2281. https://doi.org/10.1016/j. biocon.2011.06.004. 

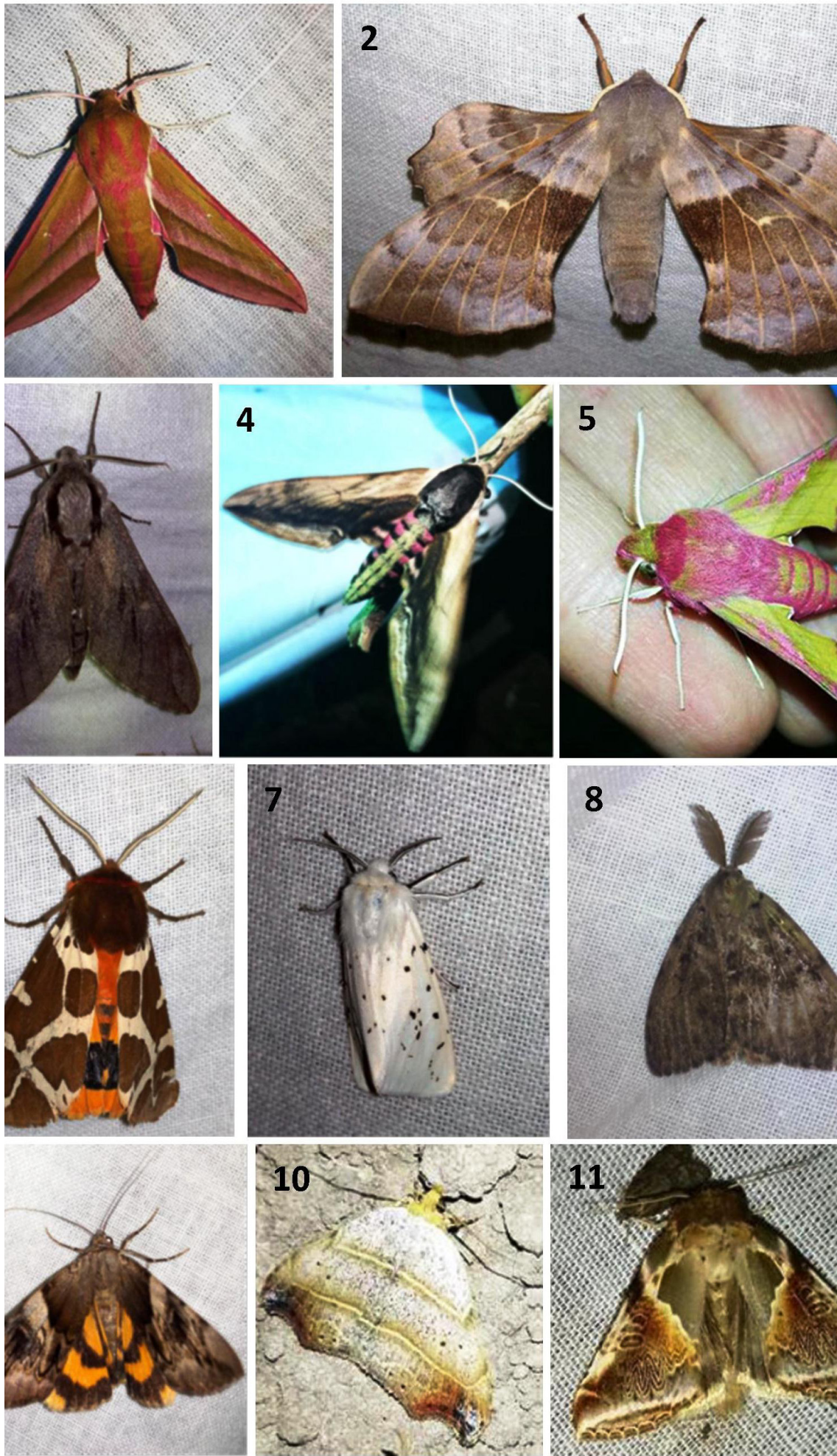

Note: Family Sphingidae: 1—Deilephila elpenor (Linnaeus, 1758); 2-Laothoe populi (Linnaeus, 1758); 3-Sphinx pinastri (Linnaeus, 1758); 4-Sphinx ligustri (Linnaeus, 1758); 5-Deilephila porcellus (Linnaeus, 1758). Family Erebidae: 6-Arctia caja (Linnaeus, 1758); 7-Spilosoma lubricipeda (Linnaeus, 1758); 8Lymantria (Porthetria) dispar (Linnaeus, 1758); 9-Catocala fulminea (Scopoli, 1763); 10-Laspeyria flexula (Denis \& Schiffermüller, 1775). Family Drepanidae: 11—Habrosyne pyritoides (Hufnagel, 1766).

Figure 3. Some of specimens representing families of the moths on studying area 

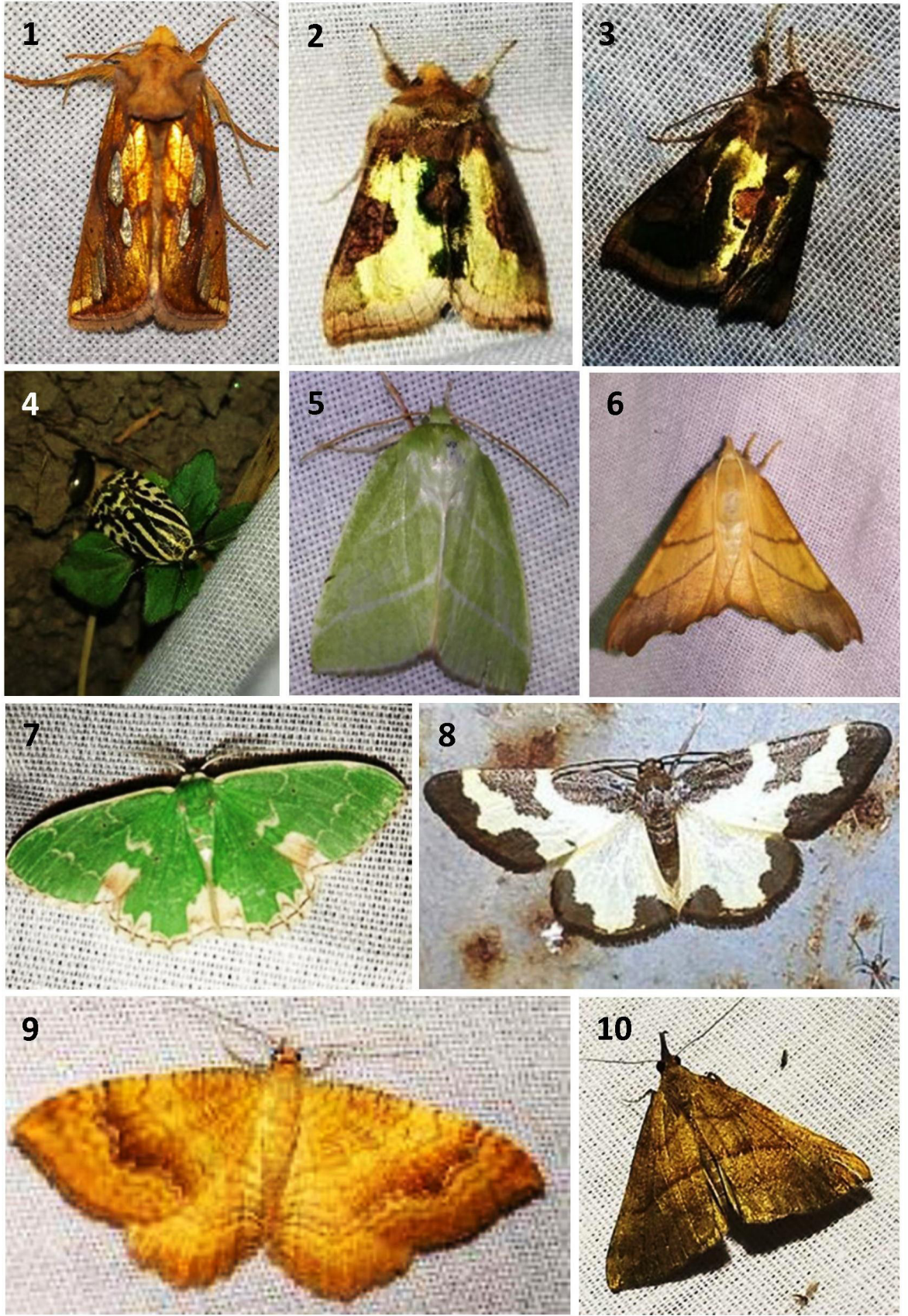

Note: Family Noctuidae: 1-Plusia festucae (Linnaeus, 1758); 2-3-Diachrysia chrysitis (Linnaeus, 1758); 4-Acontia (Emmelia) trabealis (Scopoli, 1763). Family Geometridae: 5-Pseudoips prasinana (Linnaeus, 1758); 6-Ennomos fuscantaria (Haworth, 1809); 7—Comibaena bajularia (Denis \& Schiffermüller, 1775); 8—Lomaspilis marginata (Linnaeus, 1758); 9—Camptogramma bilineata (Linnaeus, 1758); 10—Hypena proboscidalis (Linnaeus, 1758).

Figure 4. Some of specimens representing families of the moths on studying area 

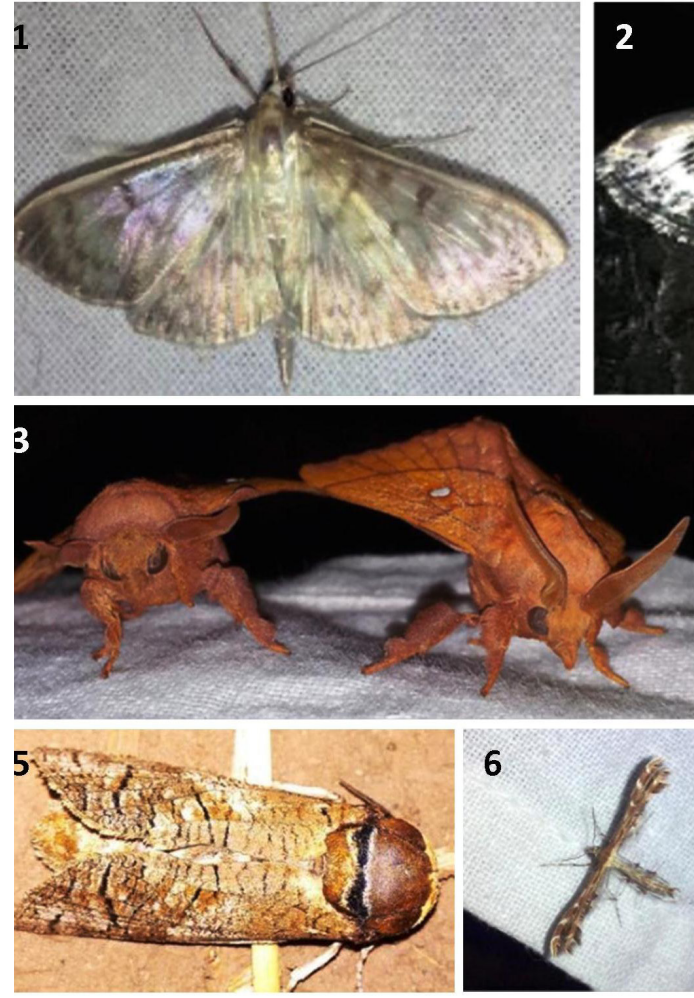

6
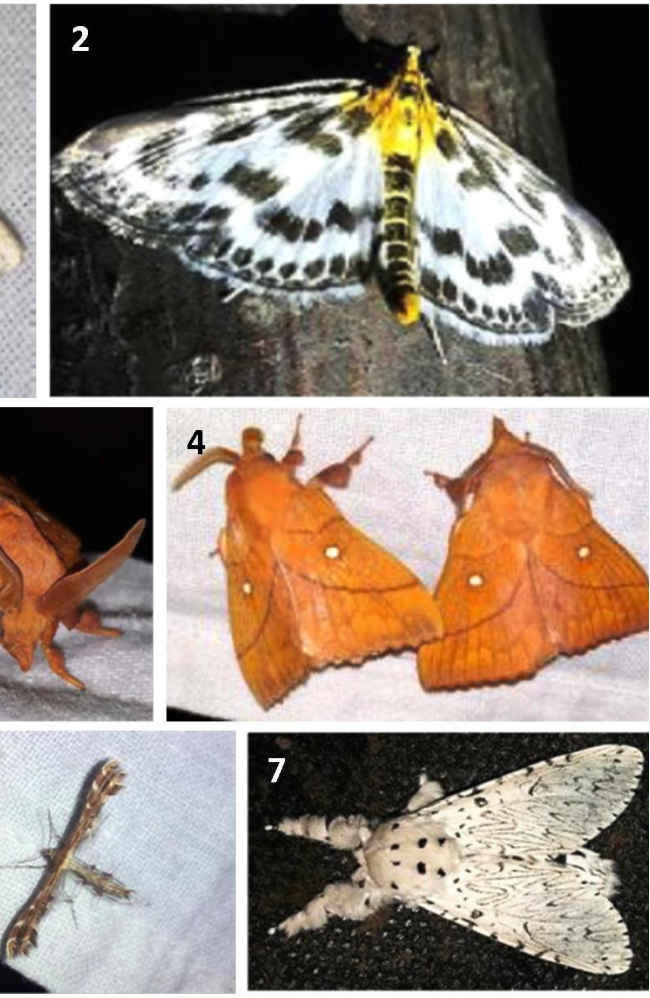

Note: Family Crambidae: 1-Patania ruralis (Scopoli, 1763); 2-Anania hortulata (Linnaeus, 1758). Family Lasiocampidae: 3-4_Odonestis pruni (Linnaeus, 1758). Family Cossidae: 5—Cossus cossus (Linnaeus, 1758). Family Pterophoroidea: 6-Oxyptilus pilosellae (Zeller, 1841). Family Notodontidae: 7-Cerura (Apocerura) erminea (Esper, 1783).

Figure 5. Some of specimens representing families of the moths on studying area 